\title{
Ekşi Elmalar Film Afişi Üzerine Göstergebilimsel Bir Deneme
}

Kenan DEMİR ${ }^{1}$

\section{Özet}

İnsanoğlu tarih boyunca kendini sözlü ve yazılı olarak ifade etmenin birçok yolunu bulmuştur. Bununla birlikte görsellik, mağara resimlerinden günümüzdeki muazzam yapılara dek insanın temel ifade aracı olma özelliğini sürdürmüştür. Sinema da icadından bu yana görsel öğeler aracılı̆̆ıyla bireyin kendini ifade etmesi için yeni imkânlar sunmuştur. Afişler ise bir filmi tanıtmak amacıyla hazırlanan görsel iletişim araçlarıdır ve seyircinin film hakkında fikir sahibi olması bakımından önemlidir. Bu çalışmada son dönem Türk sinemasında gerek oyuncu gerekse de yazar ve yönetmen olarak birçok çalışmaya imza atan Yılmaz Erdoğan'ın Ekşi Elmalar filminin afişi Roland Barthes'in göstergebilimsel analiz yöntemi ile incelenmiş̧tir. Çalışmada gösterenle gösterilen arasındaki ilişki incelenerek düzanlamın ötesine geçilmesi amaçlanmıştır. Böylece bir film afişinden hareketle dönemin toplumsal dinamiklerinin irdelenmesi hedeflenmektedir.

Anahtar Kelimeler: Göstergebilim, Barthes, Sinema, Film Afişi.

\section{A Semiotics Study On The Movie Ekşi Elmalar}

\begin{abstract}
Mankind has found various written and oral means to express himself. However, from the cave pictures to the magnificent buildings of today, visuality has maintained its quality as the main means of expression for mankind. Cinema has provided him with new opportunities to express himself via visual factors since its invention. Movie posters are visual communication tools prepared with the purpose of introducing a movie to the audiences and they are essential in terms of informing the audience about the movie. In this study, Y1lmaz Erdoğan's- who has carried out many projects in Turkish cinema not only as an actor but also as a script writer and a director- Ekşi Elmalar movie's poster is analyzed with Roland Bartes's semiotics approach.
\end{abstract}

\footnotetext{
1 Doktora Öğrencisi, Kocaeli Üniversitesi, Sosyal Bilimler Enstitüsü, Iletişim Bilimleri Anablim Dalı kenandmr06@hotmail.com Orcid ID: 0000-0001-8314-6475

Bu makaleye atıf için: Demir, K. (2021). Ekşi Elmalar Film Afişi Üzerine Göstergebilimsel Bir Deneme. Aksaray Iletişim Dergisi, 3(1), 1-15. doi:10.47771/aid.721108
} 
It is aimed to go beyond denotation by analyzing the relation between signifier and signified. Another purpose is to study social dynamics of the period via moving from a movie poster.

Key Words: Semiotics, Barthes, Cinema, Movie Poster.

\section{Giriş}

Görme konuşmadan önce gelmiştir. Çocuk konuşmaya başlamadan bakıp tanımayı öğrenir (Berger, 2016: 7). Gerçekten de insanlık tarihi incelendiğinde her dönemde görsel kültürün insanın kendini ifade etmesinde önemli bir rol oynadığı görülür. Görülebilen her şey görseldir; fakat daha dar bir kapsamda güzel sanatlar, resimler veya imgeler görsel olarak nitelenebilir. Kültür ise halk kültüründen seçkin kültüre kadar geniş bir tanım içermektedir. Bununla birlikte bir şeyin görsel kültür olabilmesi için belirli kodlar marifetiyle kültürel olarak anlamlandırılması gerekir (Barnard, 2010: 26). Görsel kültürün bir diğer tanımı da Nicholas Mirzoeff (1998: 3) tarafından şu şekilde yapılmaktadır: “Görsel kültür, günlük yaşamımızın bir parçası değil, günlük yaşamımızdır... Kültürün bu yeni görselliğini gözlemek artık onu anlamakla aynı şey değildir... Bu da görselliği çağdaş kültür için bir araştırma alanı haline getirir..." Bu tanımlar 1şı̆̆ında görsel kültürdeki görselin iletişimsel veya işlevsel bir fonksiyonunun olması gerektiği belirtilebilir. Doğadaki her şey görseldir; fakat işlevsel veya iletişimsel bir amacı olmayabilir. İşte bu nedenle görselin kültüre dönüşmesi insan ürünü olmasını zorunlu kılmaktadır.

Yukarıdaki tanımlar 1şı̆̆ında herhangi bir görselin neden öyle görüldüğü sorusundan hareketle yeni sorular sorulabilir. Bu sorular dış göstergeler (eserin sunulduğu ortam) ve iç göstergeler (eserdeki renkler, şekiller, dokular...) çerçevesinde derinleştirilebilir.

\section{Görsel Kültür ve Film Afişleri}

Türk Dil Kurumu Sözlüğü’nde afiş bir şeyi duyurmak veya tanıtmak amacıyla hazırlanan, kalabalığın görebileceği bir yere asılmış, genellikle resimli duvar ilanı olarak tanımlanmaktadır. Fransızca kökenli bir kelime olan afiş sözcüğünün İngilizce karşılığı posterdir (Türk Dil Kurumu, 2020). Becer’e (1997) göre afişs sanat ve tasarım kaygısının eşit ağırlıkta olduğu grafik ürünleridir. Afiş tasarımını yapan grafik sanatçıları öncelikli olarak tasarımlarında görsel açıdan güzel olan unsurlar yardımıyla iletecekleri mesajın etkisine bakarlar. Bu nedenle de tasarımlarında yaratıcılığa önem verirler. "Tasarımcı, afişlerde hedef kitlenin ilgisini çekecek işaretler ve simgeler kullanır. Kullanılan bu işaret ve simgelerle tanıtımı yapılan ürünün akılda kalması hedeflenir. Burada önemli olan verilecek mesajı etkin ve doğru bir sunum yöntemiyle ulaştırmaktır” (akt. Acar ve Yağbasan, 2014: 206). Sinemanın 
yaygınlaşması ve matbaacılık teknolojilerinin gelişmesiyle birlikte afişler filmleri tanıtmak için kullanılan yeni bir araç olarak ortaya çıkmıştır. Bir film afişinin diğer posterlerden en büyük farkı doğrudan belirli bir kitleyi hedeflemesidir. Daha açık bir ifadeyle bir film afişi ilk bakışta hangi tür filme ait olduğunu belli etmelidir ve afişin hedef kitlesi bu türün izleyicileridir (Fagerholm, 2009: 6). Bir film afişi tanıttığ filmle ilgili izleyiciye birçok ipucu vermekle kalmaz aynı zamanda üretildiği dönemin ve toplumun yaşam tarzı, hayata bakışı ve sosyal yapısı gibi özellikleri hakkında da doğrudan veya dolaylı bilgiler barındırır. Daha açık bir ifadeyle bir film afişi üretildiği dönemden bağımsız düşünülemez ve o dönemde yaygın olan sanat anlayışının özelliklerini yansıtması da beklendik bir durumdur. Film afişlerinin bir diğer önemli özelliği de filmin ilk gösterimine kadar seyirciye ipucu veren en değerli kaynak olmasıdır. Seyirci filmi izledikten sonra filmle ilgili gizem ortadan kalkar. Bununla birlikte seyircinin afiş̧le ilgili ilk izlenimi akıllarında yer eder. Bir film afişi yedi metreden harika görünmelidir. Bununla birlikte yakından bakıldığında seyirciyi cezbedecek bir şeyler de barındırmalıdır. Seyirci üzerinde bu etkinin sağlanması tasarımın iyi olması ve renklerin doğru kullanımı ile ilgilidir (Foster, 2006: 108). Afiş tasarımları her ne kadar özgün birer çalışma olsa da filmlerin türlerine göre ortak bazı nitelikleri olduğu açıkça görülebilir. $\mathrm{Bu}$ ortak dilin yaratılması tasarımda kullanılan öğelerle mümkün olmuştur. Bir afiş tasarımın öğeleri kullanılan resimler, illüstrasyonlar, yazı karakteri ve fontu (tipografi) ve renk tonlaması olarak sıralanabilir. Farklı film türlerinin afişlerini birbirinden ayıran temel özellik kullanılan renklerdir (Fagerholm, 2009: 7). Renklerin hayatımız üzerindeki etkisi düşündüğümüzden çok daha kapsamlı ve derindir. "Renkler düşündüğümüzden daha uzun bir süredir hayatımızın bir parçasıdır. Renkler doğal olarak insanoğlunun evrimsel sürecinin bir parçası olmuştur. Çünkü atalarımız neyin yenilebilir olduğunu, neyin zararlı olduğunu renkler sayesinde belirlemişlerdir" (Ambrose ve Harris, 2005: 6). Bu nedenle film afişlerindeki temel farkların renkler üzerinden kurulduğu söylenebilir. Bu noktada renklerin temsil ettiği anlamlar üzerinde durmanın faydalı olacağı düşünülmektedir:

Kırmızı: Kırmızı ateşin ve kanın rengidir. $\mathrm{Bu}$ nedenle enerji, savaş, tahammül, tehlike, kararlılık anlamlarını taşır. Ayrıca Batı toplumlarında kırmızı aşk, tutku ve cinsellikle ilişkilendirilmektedir. Buna ek olarak cesaretle ilişkilendirildiği için birçok ulusun bayrağında kırmızıyı kullanmayı tercih etmiştir. İnsan metabolizmasını hızlandıran ve solunum hızını artıran bu rengin görünürlüğü çok yüksektir. Bu nedenle tehlike ve uyarı işaretlerinde kırmızının kullanımı çok yaygındır (Pan, 2016). 
Pembe: Pembe, gençlik ve kadınsılıkla ilişkilendirilir. Pembenin yoğun tonları gençliği ve canlılığı vurgular. Bununla birlikte açık pembe tonları olgunluğu ve inceliği ön plana çıkarır (Ambrose ve Harris, 2005: 110).

Turuncu: Ateşin rengi olan turuncu en sıcak renklerden biridir. Bilindiği üzere bu renk ismini bir meyveden almıştır ve bu nedenle meyvelerle ilişkilendirilmesi doğal bir sonuç olarak görülebilir (Ambrose ve Harris, 2005: 112). Ateşi temsil etmesinden ötürü aksiyon filmlerinin afişleri için uygun bir seçim olan turuncu dikkatli kullanılmazsa özellikle afişteki yazıların komik görünmesine neden olabilir.

Sarı: Sarı insan gözünün görebileceği en parlak renktir. Bu nedenle afişlerde kullanımı yaygındır. Özellikle dedikodu dergileri, kapaklarında bu rengi kullanmayı tercih eder. Bilindiği üzere Amerika'da tabloid basın "Sarı Gazetecilik" olarak tanımlanmaktadır (Ambrose ve Harris, 2005: 114). Siyah ile sarı arasındaki zıtlık bu rengin uyarı levhalarında kullanılmasına imkan tanır. Genel olarak güneşli yaz günlerine atıfta bulunan sarının açık tonları heyecana, neşeye, mutluluğa işaret ederken koyu sarı daha karamsar duyguları ifade edebilir (Olesen, t.y.).

Kahverengi: Toprağın rengi olan kahverengi izleyicinin geçmiş deneyimlerine bağlı olarak olumlu veya olumsuz imalar içerebilir (Fagerholm, 2009: 14). Kahverengi toprağın sıcaklığı, sağlamlığı ile güveni çağrıştırabilir. Tam aksine izleyicinin geçmiş deneyimleri nedeniyle kir veya sıkıntı ile de ilişkilendirebilir. Posterlerde çok fazla tercih edilmeyen kahverengi son yıllarda kahve ve deri kıyafet reklamlarıyla popülerlik kazanmaya başlamıştır.

Mavi: Rahatlatıcı ve sakinleştirici bir etkisi olan maviyle ilgili yapılan bazı çalışmalar beynin bu rengi algıladığı zaman sakinleştirici bir kimyasal salgıladığını göstermektedir (Eiseman, 2000: 39-40). $\mathrm{Bu}$ nedenle ameliyathanelerin duvarlarında, cerrahların ve hemşirelerin önlüklerinde bu renk tercih edilir. Bununla birlikte bu rengin aşırı kullanımı hastaneyi ve hastalığı çağrıştırabilir. Mavi rengin melankoliyle olan ilişkisi İngilizcedeki feeling blue (kendini mutsuz hissetmek) deyimiyle de ifade edilebilir (Feel Blue, t.y.). Son tahlilde mavi güvenilir olmayı, ilham vermeyi ve kendini adamayı çağrıştırır.

Yeşil: Yeşil doğanın ve huzurun ve saflığın rengidir. Yeşilin varlığı insana huzur verir. Ayrıca Amerikan Dolarının rengi olmasından ötürü yeşil zenginliği ve prestiji çağrıştırabilir (Eiseman 2000:44). Yeşil aynı zamanda İslamı temsil eder ve birçok Müslüman ülkenin bayrağında yeşil kullanılır (Akyüz, 2014). Olgunlaşmamış meyvelerin genelde yeşil olmasından dolayı bu renk tecrübesizlik ve toylukla da ilişkilendirilebilir. 
Mor: Mor kırmızının enerjisini ve mavinin huzurunu aynı anda temsil eder. Bu renk asaleti, zenginliği ve şatafatı çağrıştırır. Çocuklar mor rengi diğer tüm renklere tercih ederler (Pan, 2016).

Beyaz: Beyaz saflığın ve masumiyetin rengidir. Bu nedenle Batı kültüründe gelinlikler için tercih edilen renk beyazdır. Ayrıca beyaz temizliği ve hijyeni çağrıştırır. Bununla birlikte doğuya özgü bazı kültürlerde beyaz ölümün ve yasın sembolüdür (Ambrose ve Harris, 2005: 126). Beyaz bayrağın teslim olmak için kullanılması beyazın korkaklıkla ilişkilendirilmesine neden olabilir (Fagerholm, 2009: 16).

Siyah: Siyah birçok duyguyla ilişkilendirilebilir. Örneğin; asalet, karizma, zenginlik, cinsel albeni siyahla ilişkilendirilen bazı durumlardır. Özellikle siyah takım elbise, kravat ve araba güç ve zenginliği akla getirir. Tüm bu olumlu çağrışımlara rağmen siyah karanlığın rengidir ve karanlık da bilinmezliğin, korkunun ve farklı olanın simgesidir. Bu nedenle sinemada özellikle korku filmleri siyah tonlarından faydalanır. Bu arada siyahın Batı kültüründe ırkçı imalar taşıdığı da dikkate alınmalıdır.

Gri: Gri kafa karışıklığını veya kaybolmuşluğu temsil eder. Olumlu ya da olumsuz bir anlam taşımayan gri zaman içinde gelen bilgeliğe de atıfta bulunur. Bununla birlikte teknoloji, uzay ve modernleşme metalin rengi olması nedeniyle gri ile temsil edilir.

Renklerin temsil ettiği anlamlarla ilgili bu genel açıklamadan sonra Ambrose ve Harris'in (2005) betimlemelerinden faydalanılarak temel film afişi türleri hakkında bilgi verilecektir. Örnek olarak verilen afiş görselleri 12.02.2020 tarihinde www.google.com üzerinden yapılan tarama sonucu rastgele seçilmiştir.

Komedi: Komedi türündeki film afişlerinin ortak özelliği kullanılan resimlerin veya illüstrasyonların güldürü unsurunu ön plana çıkarmasıdır. Bu nitelik de özellikle film oyuncularının jest ve mimikleri aracılığıyla göz önüne serilmektedir. Renk seçimi dikkat çekici ve canlı renkler doğrultusundadır. Bununla birlikte temel amaç seyirciyi eğleneceklerine ikna etmektir. Kullanılan tipografi renklidir ve harflerin boyutlarında farklılık görülebilir. Afişte keskin hatlı harflerden kaçınılır. 
Resim 1: Norbit (2007)

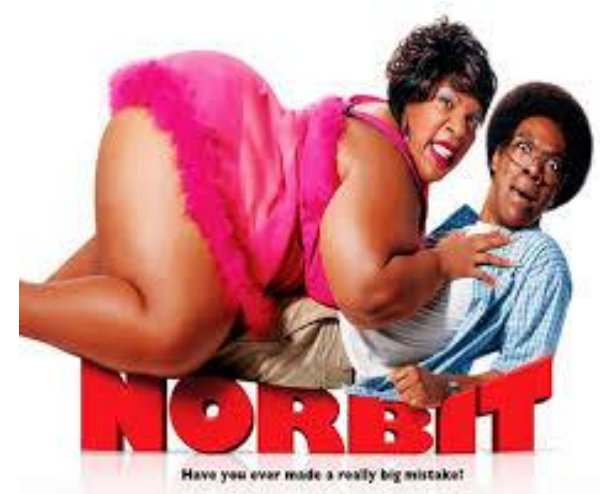

Resim 2: School of Rock (2003)

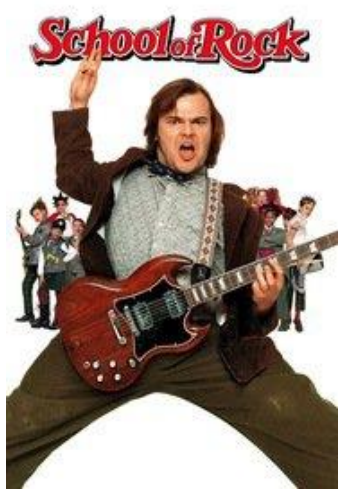

Bilim kurgu: Bilim kurgu filmlerinin posterlerinde futuristik bir yaklaşım tercih edilir. Özellikle gri ve siyah tonları en fazla karşımıza çıkan renklerdir. Ayrıca tipografi daha kesin hatlıdır ve bazı tasarımlar marjinal olarak nitelenecek kadar kendine özgüdür.

Resim 3: Avatar (2009)

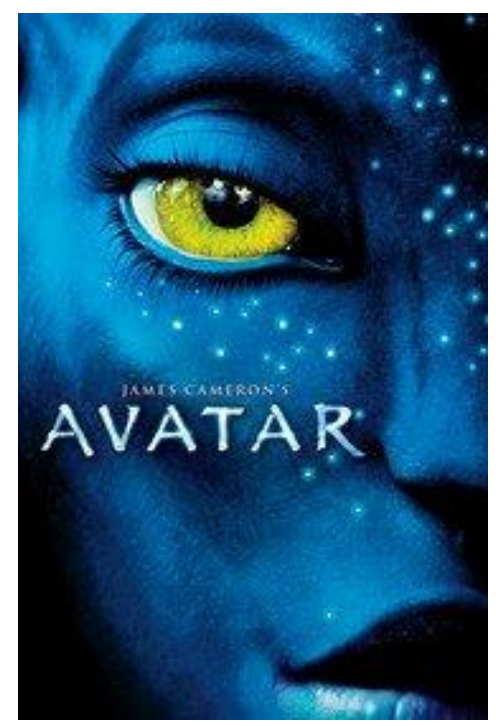

Resim 4: Inception (2010)

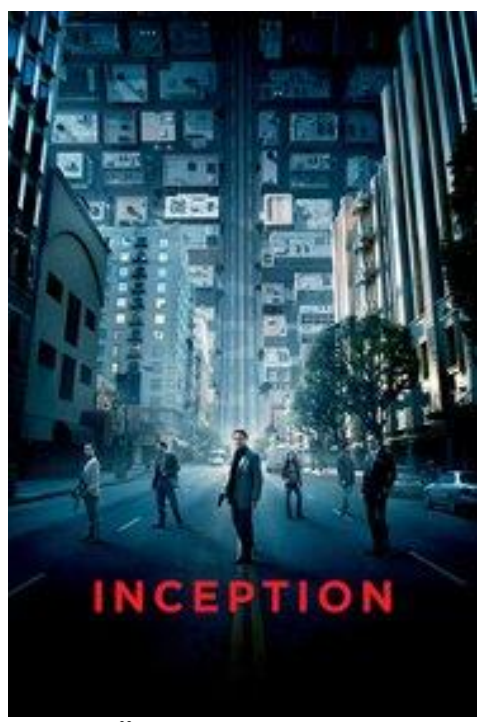

Aksiyon Filmleri: Bu türün afişlerinde sıcak renkler tercih edilir. Özellikle heyecan ve hareketi simgelemek adına bolca kırmızı tonlardan faydalanılır. Poster tasarımında genellikle filmdeki aksiyona gönderme yapan sahneler kullanılır. Tipografi ve harflerde kullanılan renkler de hareket öğesine vurgu yapar. 
Resim 5: Huntsman (2016)

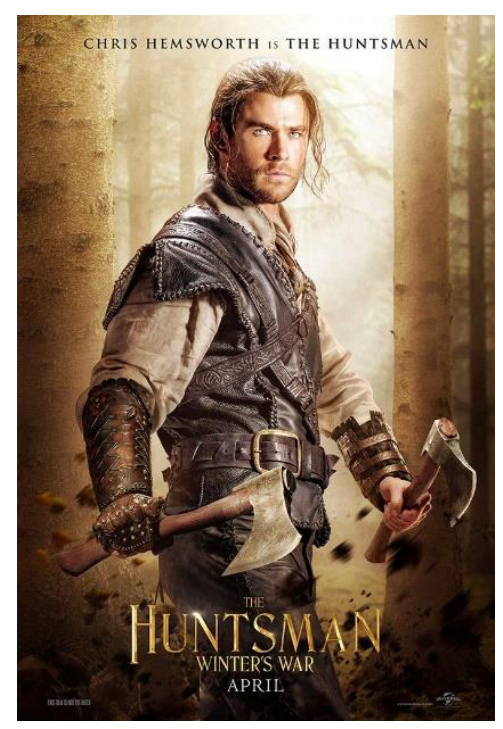

Resim 6: Elite Squad Squad (2016)

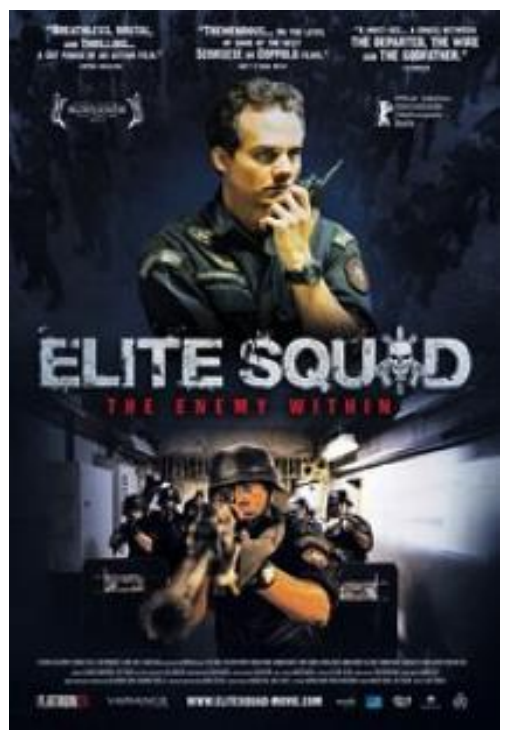

Dramatik Filmler: Dram öğesinin ön plana çıtı̆̆ı filmlerde tercih edilen afiş tasarımı hüzünlü renkler üzerine kurulur. Özellikle mavi tonlarının ve soluk renklerin ağırlıkta olduğu dramatik film afişlerinde sade bir tipografi kullanılır. Oyuncuların afişteki jest ve mimikleri seyirciye filmle ilgili ipucu verir.

Resim 7: Shawshank Redemption (1994)

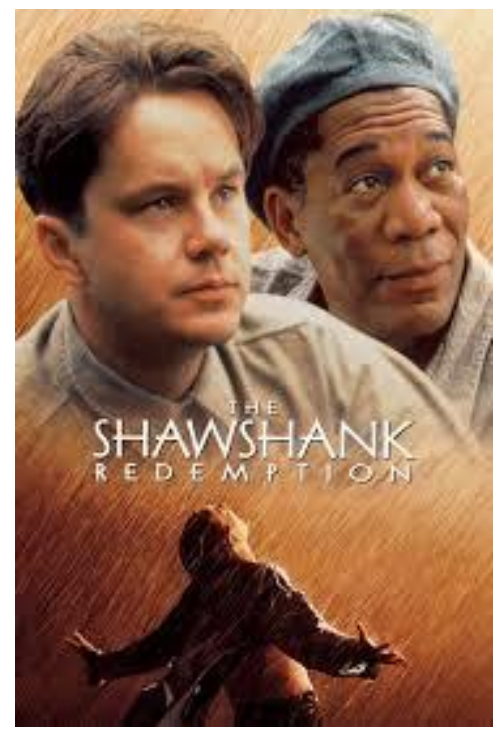

Resim 8: Babam ve Oğlum (2005)

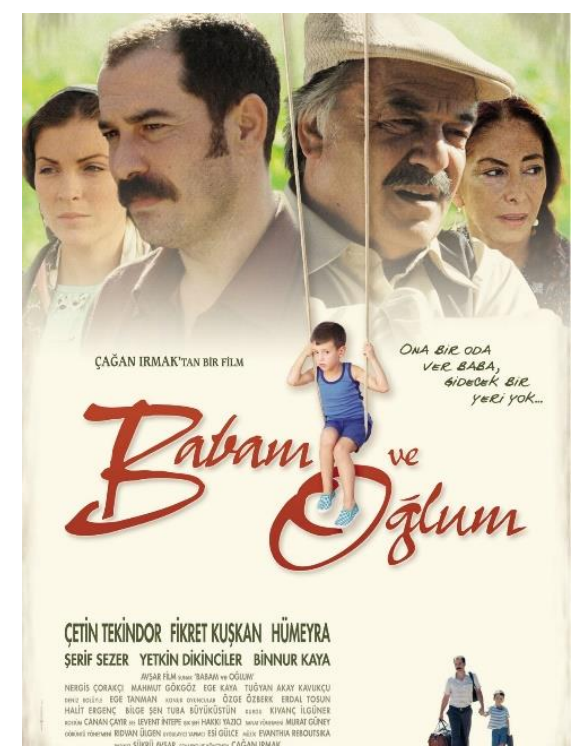

Romantik Filmler: Günümüzde özellikle komedi ve aşk bağlamları sıklıkla bir arada kullanıldığı için bu iki türün afiş tasarımlarını ayırmak zordur. Bununla birlikte romantik filmlerin tasarımında pembenin hâkimiyeti yadsınamaz bir gerçektir. Ayrıca masumiyete ve evliliğe atıfta bulunmak için beyaz da tercih edilebilir. Tipografide daha klasik bir tarz benimsenir. 
Resim 9: Silver Lining Playbook (2012)

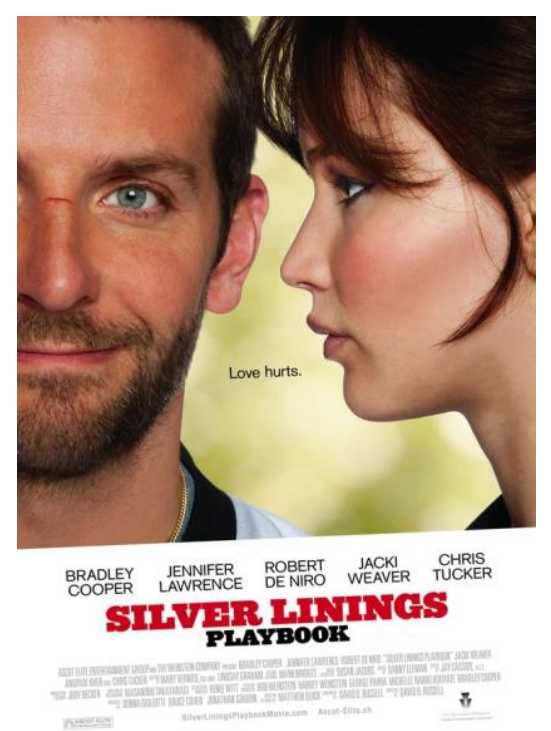

Resim 10: Chasing Liberty (2004)

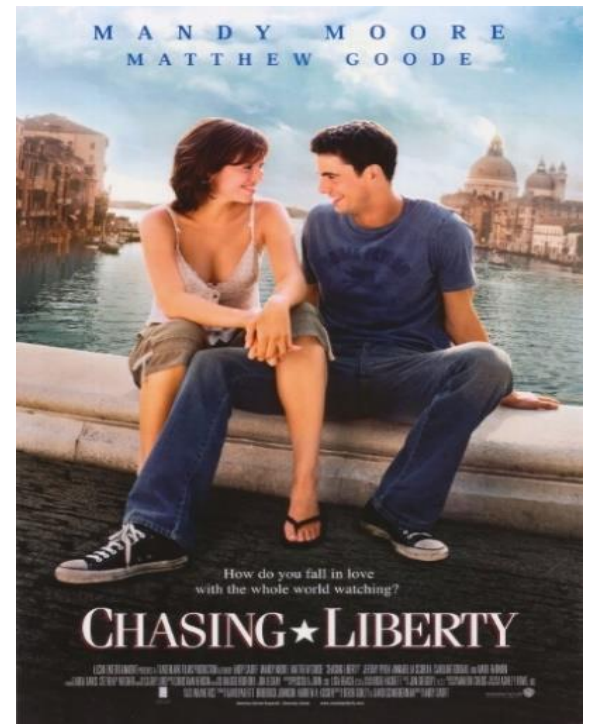

Korku Filmleri: Siyahın baskın olduğu korku filmi afişlerinde genellikle gotik bir tarz benimsenir. Korku öğesini ön plana çıkarmak için kırmızı da tercih edilebilir. Ayrıca tipografi de gotik öğeler barındırır. Gölgeler, belli belirsiz figürler sıklıkla tercih edilen görsel öğelerdir.

Resim 11: Haunted 333 (2015)

Resim 12: Silent Retreat (2013)
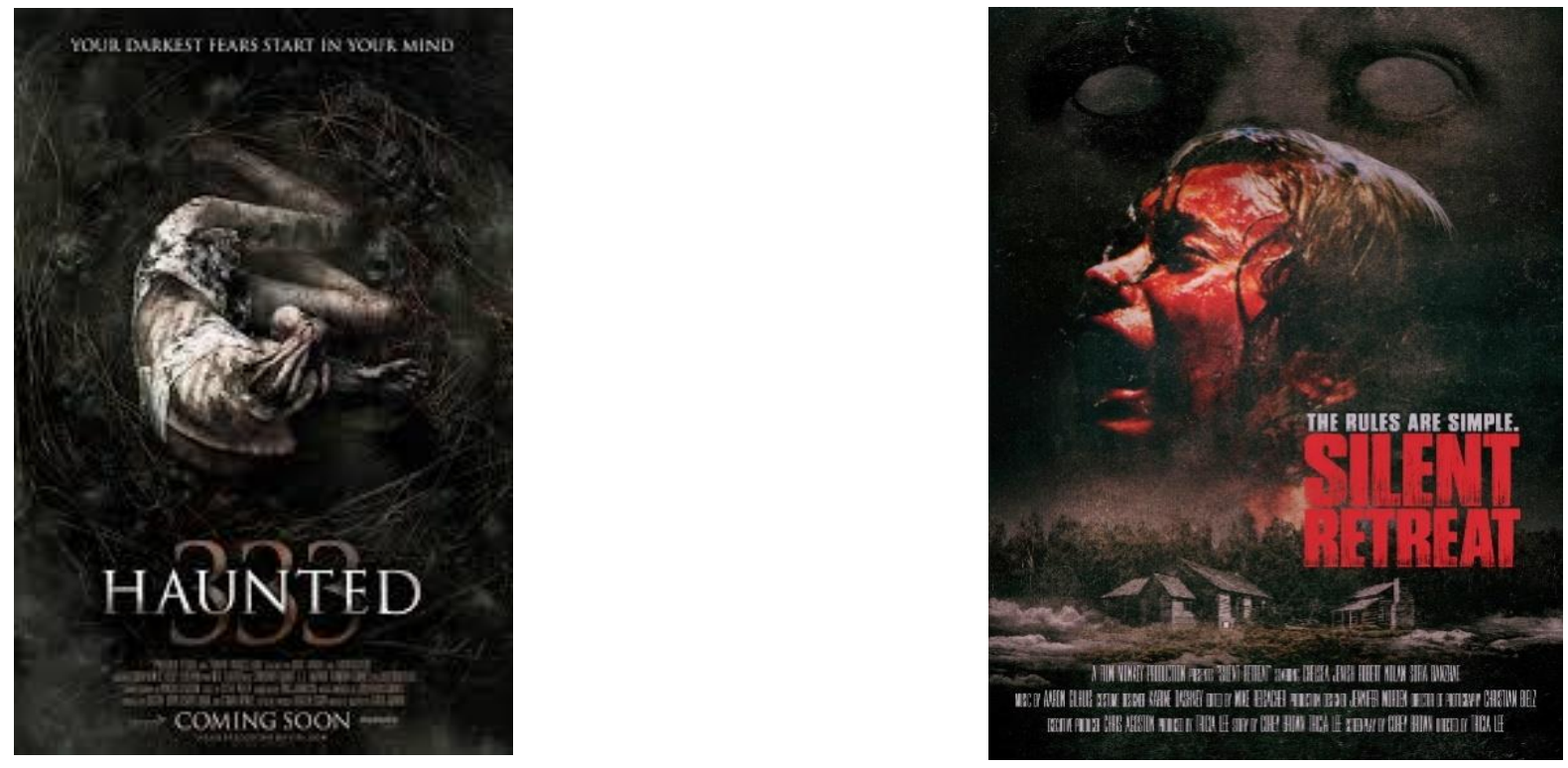

\section{Yöntem}

Çalışmamızın teorik ayağını göstergebilimsel analiz oluşturmaktadır. Tarihin sayfaları karıştırıldığında mağaranın iç duvarlarına geyik resmi çizen avcının da, devasa binalar inşa 
eden Roma İmparatorlarının da, dumanla işaret veren yerlilerin de, günümüzdeki insan aklının sınırlarını zorlayan internet devriminin de iletişim sürecinin bir parçası olduğu yadsınamaz bir gerçektir (Türkoğlu, 2010: 9). Buna rağmen iletişim kurmakta resim yazıdan çok önce gelmiştir. Tarihte bilinen ilk mağara resimleri ve semboller (kırmızı noktalar, el baskıları) İspanya'nın Kantabira şehrinde bulunmuştur ve MÖ 39000-35500 y1llarına tarihlenmektedir (Prehistoric Cave Painting, t.y.). Modern alfabeye giden yolda piktogram denilen resim yazılar kullanılmıştır. Tüm bu bilgiler ışığında görsel iletişimin, iletişim kurmanın en kolay yollarından biri olduğu ifade edilebilir. İster görsel iletişim olsun ister sözel iletişim olsun; iletişimin özünde çeşitli göstergelerden oluşan dizgeler vardır. Bu göstergelerin göstergebilim açısından incelenip anlamlandırılması göstergebilimin doğmasına neden olmuştur (Denli, 1997: 25). Göstergebilim; seslerden, işaretlerden, imgelerden, kelimelerden anlam çıkarmayı amaçlayan bir bilim dalıdır ve nesnelliği merkeze alan göstergebilimde insanla alakalı her şeyin göstergeler aracılığıyla incelenebileceği varsayılır (Erkman ve Akerson, 2005: 14). Göstergebilimin doğmasında en büyük pay İsviçreli bilim adamı Ferdinand de Saussure'e (1857-1913) ve Amerikalı Filozof Charles Sanders Peirce'a (1839-1914) aittir. Adı geçen bilim insanları neredeyse eş zamanlı olarak birbirlerinden habersiz bir şekilde göstergebilimin temellerini atmışlardır (Vardar, 2001: 86). Göstergebilimin odak noktasında gösterge yer alır. Çalışmamızın analiz çerçevesinde başvurulan Roland Barthes Göstergebilim Illkeleri adlı eserinde göstergebilim ilkelerini "dört başlık altında ve ikili karşıtlıklar biçiminde toplar: IDil ve Söz; II- Gösterilen ve Gösteren; III- Dizim ve Dizge; IV- Düzanlam ve Yananlam (Rifat, 2009: 81). Gösteren, gösterilen ve göstergeden meydana gelen dizge düzanlamı oluşturur. Düzanlam, anlamlandırma sürecinin temel basamağını meydana getirir ve anlam görünür halden ibarettir. Yananlam dizgesi ise düzanlamın göstergesini kendi dizgesinin gösterenine dönüştürür. Barthes’e (1993: 40) göre göstergebilim, göstergelerin sosyolojik işlevini temsil eder. Örneğin gösterenler dizgesi Charlie Chaplin filmleri, sabun reklamları, kadınların magazin reklamları, avant-garde romanlar vb. şekilde karşımıza çıkar. Bir başka ifadeyle gösterge, bir gösteren ile gösterilenden kuruludur; kodlar ise göstergelerin içinde düzenlendiği ve birbirleriyle nasıl ilişkilendirildiğini gösteren sistemlerdir. $\mathrm{Bu}$ noktadan bakıldığında aslında insanların üzerinde anlam bakımından anlaştığı herhangi bir dizge göstergebilim çerçevesinde incelenebilir. Örneğin herhangi bir resim, şekil, kelime... bir göstergedir ve dolayısıyla her biri üzerinde anlaşılmış bir dilin sözleridir. $\mathrm{Bu}$ örnekleri çoğaltmak mümkündür: sinema bir dildir ve filmler o dilin sözcükleridir. Filmlerin anlamları kodlar çerçevesinde filmlerin birer birer incelenmesiyle ortaya çıkarılabilir (Atabek ve Atabek 2007: 65). Bir film afişi göstergebilimsel açıdan incelendiği zaman gösteren ile gösterilen 
arasındaki ilişki dilsel kodlar bakımından dikkatli bir şekilde değerlendirilmelidir. Daha açık bir ifadeyle posterdeki görsellerin düz anlam ve yan anlamlarının neler olduğu ve bize ne söylemek istedikleri dikkatli bir şekilde analiz edilmelidir. Dikkat edilmesi gereken bir diğer nokta da afişteki nesnelerin nasıl düzenlendiğidir.

\section{Uygulama}

Çalışmamızın uygulama kısmında tüm bu bilgiler 1şı̆̆ında Yılmaz Erdoğan'ın Ekşi Elmalar adlı filminin afişi incelenecektir. Komedi ve dram türlerinin harmanı olarak tanımlanabilecek bu film, 1970'li yıllardan 1990'lara kadar uzanan yakın geçmişimizi anlatmaktadır. Hikâye, Yılmaz Erdoğan'ın Hakkâri Belediye Başkanı olan dedesinin yaşamından esinlenilerek yazılmıştır. Filmde belediye reisi karakterine Yılmaz Erdoğan hayat vermektedir.

\section{Göstergebilimsel Çözümleme}

\begin{tabular}{llll}
\hline Gösterge Türü & Gösterge & Gösteren & Gösterilen \\
\hline Görüntüsel & İnsan & Yılmaz Erdoğan & Reis \\
\hline Görüntüsel & İnsan & Songül Öden & Reis'in kızı \\
\hline Görüntüsel & İnsan & Farah Zeynep & Reis'in kızı \\
& & Abdullah & \\
\hline Görüntüsel & İnsan & Şükran Ovalı & Reis'in kızı \\
\hline Görüntüsel & İnsan & Devrim Yakut & Reis'in eşi \\
\hline Görüntüsel & İnsan & Şükrü Özyıldız & Ankara'dan gelen genç \\
\hline Görüntüsel & İnsan & Ersin Korkut & Ankara'dan gelen gencin kuzeni \\
\hline Görüntüsel & İnsan & Fatih Akman & Ziraat Mühendisi \\
\hline Görüntüsel & Doğa & Dağ & Özgürlük \\
\hline Görüntüsel & Doğa & At & Özgürlük \\
\hline Görüntüsel & Doğa & Koyunlar ve ova & Pastoral hayat
\end{tabular}


Resim 13: Ekşi Elmalar Film Afişsi (2016), (Beyazperde, t.y.).

YILMZZ FARAHZEYNEF SONGOL SOKRAN
ERDOGAN AEVRIM SOKRO

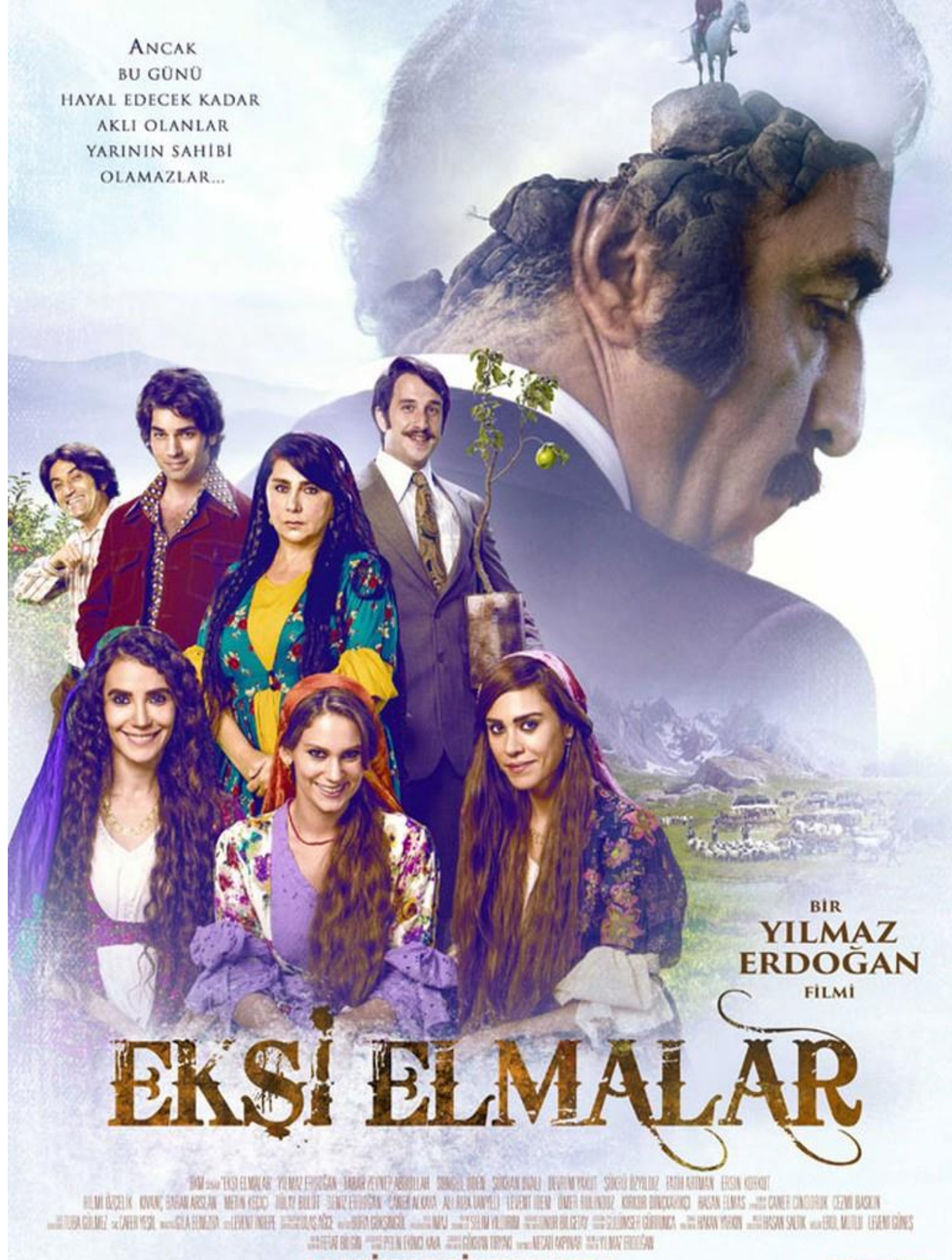

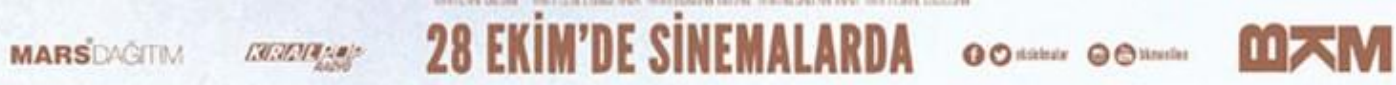


Film afişi incelendiğinde ilk olarak; fondaki Yılmaz Erdoğan (Reis) karakteri dışındaki tüm kişilerin doğrudan seyircinin gözünün içine baktığı fark edilmektedir. $\mathrm{Bu}$ da posterin ve dolayısıyla filmin "seyirlik" amaçla yapıldığının bir göstergesi olarak alınabilir. Reis'in kızlarını canlandıran (soldan) Songül Öden, Farah Zeynep Abdullah ve Şükran Ovalı yerel kıyafetler giymelerine rağmen Anadolu kadınlarının çoğunluğunun aksine başlarını tam olarak kapatmamışlardır. Bu durum yananlam düzeyinde incelendiğinde Reis'in kızlarının modern bir hayata açık olduklarını ve hatta bu hayatı istediklerini göstermektedir. Ayrıca kıyafetlerinin çiçekli oluşu ve seçtikleri örtülerin parlak renkleri hayatlarından memnun olduklarını ve yaşam sevinci ile dolu olduklarını işaret etmektedir. Bununla birlikte genç kızların annelerini canlandıran Devrim Yakut'un kıyafetleri yaşına göre oldukça renklidir. Bu durum hala hayatla canlı bir şekilde bağını sürdürdüğünün göstergesi olarak alınabilir. Buna ek olarak anne karakterinin ciddi bakışları ve hatta somurtması çocuklarını korumak isteyen bir ebeveynin kaygısını ve koruyuculuğunu yansıtmaktadır. Bu koruma güdüsünün bir diğer göstergesi de kızlarıyla kızların muhtemel erkek arkadaşları arasında bir set gibi duruşudur. Bir başka ifadeyle anne geleneksel toplum değerlerinin beden bulmuş halidir. Ayrıca ellerini bağlaması genel olarak kadının özellikle de Doğu ve Güneydoğu Anadolu Bölgesi'nde erkeğe karşı edilgen rolüne işaret etmektedir.

Takım elbiseli gencin (Fatih Akman) devlet memuru olduğu rahatlıkla anlaş1labilmektedir. Üzerindeki kıyafetler 1970'li yılların modasını yansıtmaktadır. Ayrıca elinde tuttuğu yeşil elma fidesinin bir benzerinin hemen solundaki dağda da bulunması ikisi arasındaki ilişkiyi göstermektedir. Fide dağdan alınmıştır ve dağ başına buyrukluğun ve dayanıklılı̆̆ın simgesidir. Bu arada elindeki fidesiyle gitmek üzere olduğu havasını veren takım elbiseli genç, nereye giderse gitsin yeşil elma fidesinin vatanı olan dağla ilişkisini kesmeyeceğini ima etmektedir.

Takım elbiseli gencin sağ tarafında duran ve spor bir takım giymiş olan Şükrü Özyıldız kendine güvenen bir tavır sergilemektedir. Fotoğrafa ilişmiş gibi duran ve genç kızların kuzeni rolünü canlandıran Ersin Korkut, komik bir jest yaparak kompozisyondaki komedi unsuru olduğunu adeta ilan etmektedir. Buna ilaveten afişte kapladığı alanın filmdeki rolünün boyutuna göndermede bulunduğu belirtilebilir. Ersin Korkut'un arkasında görülen kırmızı elma, fonda bir elma bahçesi olduğu izlenimini vermektedir. Reis karakterini canlandıran Yılmaz Erdoğan birbirine karışmış ve neredeyse saydam durumdaki görüntüsüyle herkesi ve her şeyi kuşatmaktadır. Ayrıca fotoğrafın sağ tarafına (pozitif alan) Reis karakterinin fotoğrafı yerleştirilmiştir, sol taraf ise negatif alan olarak kullanılmıştır. $\mathrm{Bu}$ durumda izleyicilerin 
bakışları Reis karakterine odaklanır. Reis'in saydamlaşan görüntüsü diğer karakterlerin hayatlarının her alanına nüfuz ettiğinin bir işaretidir. Bu öyle bir nüfuz ediştir ki orda olmasa bile (saydam haliyle) herkesi kuşatmaktadır. Ayrıca Reis karakterinin afişteki diğer bireylere sırtını dönmesi her ne kadar kuşatıcı olsa da herkesten ayrı bir istikameti olduğunun göstergesi olarak alınabilir. Yılmaz Erdoğan'ın yüzündeki hüzün, içinde adını koyamadığı bir şeylerin olduğuna işaret olarak alınabilir. Yılmaz Erdoğan'ın zihnindeki dağın doruğunda ata binen kişi kendisidir. Aslında bu imge Reis karakterinin ufkunun çok geniş olduğunu, herkesten farklı tasarıları, öngörüleri olduğunu işaret ediyor olabilir. Son olarak; afişin sağ alt köşesinde görülen pastoral hayat insanın doğa ile bağının sürdüğünün bir göstergesidir.

Poster tipografik açıdan incelendiğinde filmin adının büyük tırnaklı harflerle neredeyse kaligrafik olarak nitelendirilebilecek bir tarzda yazıldığı görülmektedir. İşliyen'e (2014: 68) göre büyük harflerin kullanımı ile dikkat çekilmesi amaçlanırken tırnaklar ise harfler arası geçişi kolaylaştırmaktadır. Harflerin anatomik yapısındaki tırnaklar sayesinde göz, harfleri kolayca takip edebilmektedir. Yapılan bazı araştırmalara göre tırnaklı yazılar gözü yormadığı için daha kolay okunmaktadır. Afişteki renk tercihleri incelendiğinde film ismi için haki ve kahverengi bir ton seçilerek elmanın ekşi tadına atıfta bulunulduğu görülür. Posterin fonunda beyaz ve mavi tonları tercih edilmiştir ve bu renkler ilk bakışta insanı sakinleştirmekte ve huzur vermektedir. Benzer bir ifadeyle hikaye bütünüyle huzurlu bir hayata atıfta bulunmaktadır. Fondaki pastoral hayat çoğumuzun hayalini kurduğu öze dönüşü temsil eder. Kompozisyona toplumsal gruplar ve temsil açısından baktığımızda ataerkil yapının kendini açıkça hissettirdiği görülmektedir. Baba hem koruyucu figürdür hem de otorite kaynağıdır; daha açık bir ifadeyle üretim gücünü elinde bulunduran Reis karakteri kendisi dışında kalanları ikincilleştirmiştir ve tıpkı George Orwell'in (1992) korku ütopyası 1984'teki “Big Brother" gibi her yeri kuşatmaktadır. Özellikle kadın figürlerinin ellerini önde bağlamış olmaları bu otorite karşısında kabul edilmiş bir çaresizlik içinde olduklarını göstermektedir. Buna ek olarak koyun sürülerinin özellikle Reis karakterinin gölgesi altında tasvir edilmesi adeta maddi kaynakların kimin kontrolünde olduğunu yüksek sesle söylemektedir. Fakat Reis'in afişte sırtını dönmüş olması belki de bu düzenin değişeceğine dair bir gönderme olabilir. Çünkü sırtını dönmek; uzaklaşmak, ayrılmak veya vaz geçmenin göstergesi olarak alınabilir.

\section{Sonuç:}

$\mathrm{Bu}$ çalışmada görsel kültürün bir öğesi olan Ekşi Elmalar film afişi Barthes’in göstergebilimsel bakış açısıyla incelenmiştir. Afiş herhangi bir ürünün tanıtımını yapmak 
amacıyla hazırlanan bir görsel kültür öğesidir ve aslında çoğunlukla üretildiği çağın sanatsal akımlarını da yansıtan birer sanat eseridir. Film afişleri de bu türün en yaygın örneklerinden birini oluşturmaktadır. Herhangi bir eserde olduğu gibi film afişlerinin de renk ve tasarım gibi öğeleri vardır. Özellikle de renkler afiş tasarımının en temel öğesidir. Eş bir ifadeyle afişlerde seçilen renkler rastlantısal değildir. Bununla birlikte bir film afişini analiz etmek için çeşitli yöntem ve yaklaşımlara başvurulabilir. Göstergebilim de bu yöntemlerden biridir ve çalışmada afiş analizi için bu yöntem tercih edilmiştir. Barthes'in (1993) belirttiği üzere gösteren, gösterilen ve göstergeden ibaret olan yananlam düzanlamı kendi göstergesine dönüştürür ve herhangi bir göstergeye içinde meydana geldiği toplumun değerleri dahilinde yeni anlamlar yükler. Bu noktadan hareketle çalışmada Türkiye'nin günümüzde olduğu kadar yakın geçmişinde de bağlayıcı olan erkek egemen toplum, kadınları edilgenleştiren bakış açısı gibi birçok toplumsal dinamiğin bir afiş üzerinden temsil edildiği görülmektedir. Sonuç olarak göstergebilimsel bir bakış açısının kazanılması görünenin arkasındakinin fark edilmesini mümkün kılmaktadır.

\section{Kaynakça}

Acar, Mehmet ve Yağbasan, Mustafa (2014), Minimalist Sanat Akımına Dayalı Olarak Yavuz Turgul Filmleri ve Afiş Önerileri, Fırat Üniversitesi Sosyal Bilimler Dergisi, 24(2), S. 205-220.

Akyüz, Hüseyin, (2014), “Hz. Peygamber'in Hadislerinde Renklerin Dili”, Atatürk Üniversitesi İlahiyat Fakültesi Dergisi, 0 (41), 373-398.

Ambrose, Gavin \& Harris, Paul (2005), Colour, AVA Publishing SA, Lausanne.

Atabek, Gülseren ve Atabek Ümit (2007), Medya Metinlerini Çözümlemek. Siyasal Kitabevi, Ankara.

Barnard, Malcom (2010), Sanat, Tasarım ve Görsel Kültür, Ütopya, İstanbul.

Barthes, Roland (1993), Göstergebilimsel Serüven, Yapı Kredi Yayınları, İstanbul.

Becer, Emre (1997), İletişim ve Grafik Tasarımı, Dost Kitapevi, Ankara.

Cecilia, Fagerholm (2009), The Use Of Colour in Movie Poster Design An Analysis Of Four Genres, Metropolita.

Denli, Salih (1997), Gösterge Bilim Açısından Grafik Gösterge Anlamlarının İncelenmesi, Yüksek Lisans Tezi, Atatürk Üniversitesi, Sosyal Bilimler Enstitüsü, Erzurum. 
Eiseman, Leatrice (2000), Pantone Guide to Communicating with Color, Grafix Press Ltd, USA.

Erkman-Akerson, Fatma (2005), Göstergebilime Giriş, Multilingual, İstanbul.

Foster, John (2006), New Masters Of Poster Design - Poster Design For The Next Century, Rockport Publishers, Inc., Beverley.

İşleyen, Fadime Şimşek (2014), Gazete Tasarımının Haberin Algılanması Ve Anlamlandırılması Üzerindeki Etkisi, Doktora Tezi, Selçuk Üniversitesi Sosyal Bilimler Enstitüsü, Konya.

John, Berger (2016), Görme Biçimleri, Metis, İstanbul.

Mirzoeff, Nicholas (1998), The Visual Culture Reader, Routledge, London.

Orwell, George (1992), 1984, Penguin, New York.

Rifat, Mehmet (2009), Göstergebilimin ABC’si, Sel Yayınları, İstanbul.

Türkoğlu, Nurcan (2010), İletişim Bilimlerinden Kültürel Çalışmalara Toplumsal İletişim Tanımlar, Kavramlar, Tartışmalar, Urban, İstanbul.

Vardar, Berke (2001), Dilbilimin Temel Kavram ve İlkeleri. Multilingual Yayınları, İstanbul.

\section{Elektronik Kaynaklar}

$\begin{array}{lllll}\text { Beyazperde. } & \text { (t.y.). } & \text { Şubat } & 7, & 2020\end{array}$ www.beyazperde.com/filmler/film-240738/fotolar/ adresinden alınmıştır.

Olesen, J. (t.y.). Yellow Color Meaning - The Color Yellow Symbolizes Happiness and Optimism. Color Meanings. Şubat 5, 2020 tarihinde, www.color-meanings.com/yellow-color-meaning-the-color-yellow/ adresinden alınmıştır.

Pan (8 Mart, 2016). What Do Colors Mean and Represent?. SAE Alumni. https://alumni.sae.edu/2016/03/08/what-do-colors-mean-and-represent/ adresinden alınmıştır. Feel Blue (t.y.). Tureng Sözlük. Şubat 10, 2020 tarihinde, www.tureng.com/tr/turkce-ingilizce/feel\%20blue adresinden alınmıştır.

Türk Dil Kurumu (t.y.). Şubat 10, 2020 tarihinde, www.tdk.gov.tr adresinden alınmıştır.

Prehistoric Cave Painting (40,000-10,000 BCE) (t.y.). Visual-Arts-Cork. Şubat 5, 2020 tarihinde, http://www.visual-arts-cork.com/prehistoric/cave-painting.htm\#oldest adresinden alınmıştır. 